\title{
GAMBARAN KINERJA PETUGAS REKAM MEDIS DI RSUD CIBINONG KABUPATEN BOGOR TAHUN 2018
}

\author{
Fauziyah Ulfah ${ }^{1)}$ dan Husnah Maryati ${ }^{2)}$
}

\begin{abstract}
Konsentrasi Manajeman Pelayanan Kesehatan, Program Studi Kesehatan Masyarakat, Fakultas Ilmu kesehatan, Universitas Ibn Khaldun Bogor. Jl. K.H Sholeh Iskandar Raya Km 2, Kedung Badak, Bogor 16161, Jawa Barat.

Email: fauziyahulfah0121@gmail.com

Program Studi Kesehatan Masyarakat, Fakultas Ilmu kesehatan, Universitas Ibn Khaldun Bogor. Jl. K.H Sholeh Iskandar Raya Km 2, Kedung Badak, Bogor 16161, Jawa Barat. Email: husna.masyati@uika-bogor.ac.id
\end{abstract}

\begin{abstract}
Abstrak
Rekam medis adalah berkas yang berisi catatan dan dokumen identitas pasien, hasil pemeriksaan, pengobatan, tindakan dan pelayanan yang telah diberikan. Pengelolaan rekam medis yang baik dapat meningkatan mutu pelayanan sehingga tercapainya tertib administrasi di Rumah sakit. Salah satu indikator untuk melihat kinerja rekam medis dapat dilihat dari Standar Pelayanan Minimum Rekam Medis. Pada Tahun 2017, dari 4 indikator SPM Rekam medis terdapat 2 SPM yang belum tercapai yaitu Kelengkapan berkas rekam medis 24 jam setelah pelayanan dan kelengkapan Informed Consent setelah mendapatkan informasi yang jelas. Tujuan penelitian untuk mengetahui gambaran kinerja petugas rekam medis di RSUD Cibinong Kabupaten Bogor Tahun 2018. Penelitian ini menggunakan metode deskriptif kualitatif dengan menggunakan pendekatan studi kasus. Informan berjumlah 4 orang dan instrument yaitu pedoman wawancara mendalam, pedoman observasi, dan pedoman telaah dokumen. Di saran untuk meningkatkan komunikasi antara petugas rekam medis dengan instalasi lain yang berhubungan dengan rekam medis.
\end{abstract}

\section{Kata Kunci: Rekam Medis, Kinerja Petugas}

\section{Pendahuluan}

Performance atau kinerja adalah hasil kerja yang dapat dicapai oleh seseorang atau kelompok orang dalam suatu organisasi, sesuai dengan wewenang dan tanggung jawab masing-masing dalam rangka upaya mencapai tujuan organisasi bersangkutan secara legal, tidak melanggar hukum dan sesuai moral dan etika (Prawiranto, dalam Mulyono, 2012). Menurut Mathis \& Jackson (2006) dalam kurniawati dkk (2015), Kinerja para karyawan individual adalah faktor yang mempengaruhi keberhasilan suatu organisasi.

Penilaian kinerja instalasi pemerintah dapat dilakukan secara eksternal, yaitu mengukur respon kepuasan masyarakat.
Pemerintah telah menyusun alat ukur untuk mengukur kinerja pelayanan publik secara eksternal melalui keputusan Menpan no 25/KEP/M.PAN/2/2004 tentang Pedoman umum penyusunan indeks kepuasan masyarakat unit pelayanan instansi pemerintah. (Meoheriono, dalam Sitorus (2012))

Menurut Undang-undang RI No 44 tahun 2009 tentang Rumah Sakit, Rumah Sakit adalah institusi pelayanan Kesehatan yang menyelanggarakan pelayanan kesehatan perorangan secara paripurna yang menyediakan pelayanan rawat inap, rawat jalan, dan gawat darurat. Rumah sakit 
merupakan sarana pelayanan kesehatan yang mutlak dibutuhkan oleh segenap lapisan masyarakat dalam upaya peningkatan derajat kesehatan baik individu maupun masyarakat secara keseluruhan. Rumah sakit dituntut untuk memberikan pelayanan yang memadai dan memuaskan, oleh karena itu rumah sakit hurus mampu meningkatkan kualitas pelayanannya termasuk diantaranya peningkatan kualitas pendokumentasian rekam medis (Pamungkas dkk (2010) dalam Kurniawati dkk (2015).

Keputusan Menteri Kesehatan Republik Indonesia Nomor: 377/Menkes/SK/III/2007 menyebutkan bahwa petugas rekam medis yang profesional wajib memberikan pelayanan yang berkualitas sesuai dengan standar kompetensi dan kode etik profesi. Kompetensi petugas rekam medis yaitu: Klasifikasi dan kodifikasi penyakit, masalahmasalah yang berkaitan dengan kesehatan dan tindakan medis, Aspek hukum dan etika profesi, manajeman rekam medis dan informasi kesehatan/rekam medis, kemitraan profesi (Kurniawati dkk, 2015).

Permasalahan yang pernah dihadapi oleh bagian rekam medis di salah satu rumah sakit yang menjadi tempat penelitian yang dilakukan oleh Fitra Kurniawati (2015) dengan judul "Gambaran Kinerja Petugas Rekam Medis Rumah Sakit PKU Muhammadiyah di Yogyakarta: Studi Kualitatif' menyebutkan bahwa permasalahan yang ada di rekam medis rumah sakit PKU Muhammadiyah adalah masih terdapatnya keterlambatan penyediaan berkas rekam medis pasien ke unit-unit pelayanan kesehatan serta terjadi ketidaksesuaian berkas rekam medis dengan unit pelayanan tujuan pasien, sehingga mengakibatkan keterlambatan pelayanan pasien serta mengakibatkan dokter tidak bisa mendokumentasikan pelayanan yang sudah diberikan. Pada penelitian lain yang dilakukan oleh Novi Dindatia (2017) yang berjudul "Gambaran Kinerja Petugas Rekam Medis di Rumah Sakit Umum Daerah Kota Kendiri” terdapat kendala yang dihadapi Rekam Medis di RSUD Kota Kendiri yaitu pengisian berkas rekam medis pasien yang terkadang tidak lengkap diisi lengkap, penulisan dokter yang terkadang tidak bisa dibaca dan dipahami dan pengambilan berkas rekam medis pasien terbilang lama atau tidak sesuai standar.

RSUD Cibinong merupakan salah satu Rumah sakit rujukan untuk wilayah Kabupaten Bogor. Kualitas sebuah rumah sakit dapat dilihat dari capaian indikator Standar Pelayanan Minimal (SPM). Standar Pelayanan Minimal Rekam Medis RSUD Cibinong memiliki empat indikator, yaitu 1) kelengkapan pengisian rekam medis 24 jam setelah selesai pelayanan $100 \%$; 2) kelengkapan informed concent setelah mendapatkan informasi yang jelas $100 \%$; 3) waktu penyediaan dokumen rekam medis pelayanan rawat jalan < 10 menit; 4) waktu penyediaan dokumen rekam medis pelayanan rawat inap < 15 menit. Pada Studi pendahuluan didapatkan Hasil Penilaian SPM Rekam Medis di RSUD Cibinong pada tahun 2017 menjelaskan bahwa terdapat dua indikator yang belum memcapai Standar Pelayanan Minimal yaitu kelengkapan pengisian rekam medis 24 jam setelah selesai pelayanan sebesar 37,68\% dan kelengkapan informed concent setelah mendapatkan informasi yang jelas sebesar 94,99\%. Dua indikator lain sudah mencapai Standar Pelayanan Minimal yaitu waktu penyediaan dokumen rekam medis pelayanan rawat jalan sebesar 3,28 menit dan waktu penyediaan dokumen rekam medis pelayanan rawat inap 10,75 menit. Oleh karena itu peneliti ingin melakukan penelitian Tentang Gambaran Kinerja Pegawai Rekam medis di RSUD Cibinong. 


\section{Metode Penelitian}

Penelitian dilaksanakan di RSUD Cibinong Kabupaten Bogor pada Bulan September-Oktober 2018. Desain studi penelitian kualitatif dengan pendekatan studi kasus. Pemilihan metode penelitian kualitatif dilakukan untuk memahami fenomena tentang apa yang dialami subjek penelitian, misalnya perilaku, persepsi, motivsai, tindakan, dan

\section{Hasil Penelitian}

\section{Karakteristik Informan}

Pada penelitian ini, penulis melakukan wawancara mendalam dengan 4 orang informan yang mewakili setiap bagian yang terdapat di Sub Bagian Rekam Medis. Berikut tabel yang menunjukan karakteristik informan:

Tabel 1. Karakteristik Informan Penelitian

\begin{tabular}{cllll}
\hline $\begin{array}{l}\text { Kode } \\
\text { Inform } \\
\text { an }\end{array}$ & Jabatan & $\begin{array}{l}\text { Jenis } \\
\text { Kelamin }\end{array}$ & $\begin{array}{l}\text { Lama } \\
\text { Kerja }\end{array}$ & Pendidikan \\
\hline I1 & $\begin{array}{l}\text { Kepala } \\
\text { Rekam Medis }\end{array}$ & $\begin{array}{l}\text { Perempu- } \\
\text { an }\end{array}$ & 5 tahun & $\begin{array}{l}\text { S1 } \\
\text { Kedokteran }\end{array}$ \\
\hline I2 & $\begin{array}{l}\text { Petugas } \\
\text { Pendaftaran }\end{array}$ & Laki-laki & $\begin{array}{l}3.5 \\
\text { tahun }\end{array}$ & S1 Ekonomi \\
\hline I3 & $\begin{array}{l}\text { Petugas } \\
\text { penyimpanan } \\
\text { dan } \\
\text { pengambilan } \\
\text { berkas rekam } \\
\text { medis/Petuga } \\
\text { s Kartu }\end{array}$ & Laki-laki & $\begin{array}{l}14 \\
\text { tahun }\end{array}$ & SMA \\
\hline I4 & & & \\
& $\begin{array}{l}\text { Petugas } \\
\text { pengumpulan, } \\
\text { pengolahan } \\
\text { data dan } \\
\text { pelaporan }\end{array}$ & Perempu- & 10 & \\
\hline
\end{tabular}

\section{Kinerja Petugas Rekam Medis}

Berdasarkan hasil observasi petugas pendaftaran rata-rata waktu penginputan data pasien yaitu 2 menit 1 detik dari 30 pasien yang dilayani, petugas kartu melakukan pencarian berkas rekam medis dengan waktu rata - rata untuk rawat jalan yaitu 1 menit dari 9 berkas yang dicari dan untuk rawat inap yaitu 1 meanit 22 detik dari 9 berkas yang dicari, petugas pelaporan merekapitulasi lain sebagainya. Teknik pengumpulan data meliputi data primer melalui wawancara mendalam dan observasi dan data sekunder melalui dokumen-dokumen. Informan penelitian diambil 4 orang yang terdiri dari Kepala rekam medis, petugas pendaftaran, petugas kartu, dan petugas pelaporan.

presentase kelengkapan berkas rekam medis yaitu 91,54\% dari 130 berkas yang di pengisiannya 24 jam setelah pelayanan dan presentase kelengkapan informed consent yaitu 97,36 \% dari 38 informed consent yang di periksa.

Petugas rekam medis telah melakukan tugasnya sesuai dengan tupoksi yang ada sesuai dengan bagian-bagiannya, serta secara umum output yang harapkan adalah pendistribusian berkas rekam medis ke ruang poli dapat tepat waktu, berikut adalah kutipan wawancara dengan kepala rekam medis:

“... Iya, petugas rekam medis mengerjakan sesuai tupoksi yang ada, sesuai dengan SPO” $\left(\boldsymbol{I}_{1}\right)$

“... hasil kerjanya adalah sesuai dengan pembagian tugasnya, misalnya rekam medis itu bagian dari rekam medis itu sendiri adalah kalau di RSUD Cibinong dari dia antrian, pengelolaan antrian dari dia pendaftaran, sampai pencarian berkas rekam medis, sampai berkas itu balik lagi untuk di assembling, di filling sampai untuk di simpan itu adalah tugas-tugas dari bagian rekam medis. Jadi hasilnya adalah output yang diharapkan adalah berkas rekam medis itu bisa sampai 
tepat waktunya ke poli rawat jalan untuk pelayanan kepada pasien." (II)

\section{Karakteristik Individu Petugas Rekam Medis}

\section{a) Kemampuan}

Berdasarkan hasil observasi yang dilakukan didapatkan hasil bahwa pegawai rekam medis memiliki kemampuan yang mendukung dalam hal pekerjaaannya. Kemampuan yang dimiliki petugas pendaftaran yaitu menerangkan informasi dengan jelas kepada pasien yang belum memahami alur pelayanan BPJS dan Non BPJS sehingga pasien dapat memahaminya dan mengoperasikan komputer guna menginput data pasien. Kemampuan yang dimiliki petugas kartu (pengambilan dan pendistribusian berkas) yaitu melakukan pencarian berkas dengan cepat, mengoprasikan komputer untuk mendapatkan trease dan dapat melakukan komunikasi antar petugas. Kemampuan yang dimiliki petugas pelaporan yaitu mengoperasikan komputer sesuai tugas yang di lakukan (pelaporan di bagi menjadi 4 bagian petugasan, yaitu assembling, koding, KLPCM/ Ketidaklengkapan Pengisian Catatan Medis dan laporan harian), melakukan komunikasi antar petugas, mengerjakan tugas dengan teliti, berkoordinasi dengan sesama petugas bagian pelaporan maupun bagian kartu.

\section{b) Keterampilan}

Berdasarkan hasil observasi yang dilakukan didapatkan hasil bahwa pegawai rekam medis memiliki keterampilan sesuai dengan bagian masing-masing penugasan. Petugas pendaftaran memiliki keterampilan dalam mengoperasikan komputer untuk penginputan data pasien dan memiliki public speaking yang baik kepada pasien. Petugas kartu memiliki keterampilan dalam bertindak cepat dan sigap untuk melakukan pencarian berkas. Petugas pelaporan memiliki keterampilan dalam mengoperasikan aplikasi di komputer untuk menginput data sesuai dengan pembagian tugas.

$$
\text { Berdasarkan hasil wawancara }
$$
keterampilan yang dibutuhkan disetiap bagian rekam medis berbeda-beda, berikut kutipan hasil wawancara:

"...tangkas sih, tangkas sama kecepatannya." (I $\left.\boldsymbol{I}_{2}\right)$

“...keterampilan disini paling kita harus ngapalin nomor-nomor rekam medis, ya untuk memudahkan pencarian." $\left(\mathbf{I}_{3}\right)$

“... menguasai Microsoft office ini ya excel, menguasai excel terus teliti kali ya" (I $\mathbf{I}_{4}$

Menurut kepala rekam medis keterampilan yang didapat dari pendidikan merupakan salah satu hal penting untuk melancarkan pekerjaan yang ada di rekam medis, berikut kutipan hasil wawancara:

“...yang di butuhkan, keterampilan yaitu pertama adalah mungkin pendidikan ya. Sebenernya pendidikannya itu harus, karna disini adalah sub bagian rekam medis maka harus sesuai bahwa yang mengerjakan harus lulusan-lulusan dari rekam medis seperti itu sedangkan yang non rekam medis mengerjakan istilahnya membantu untuk melancarkan kegiatan yang ada di rekam medis." (II)

\section{c) Pengetahuan}

Berdasarkan hasil wawancara yang dilakukan didapatkan hasil bahwa informan dua, tiga, empat dapat menjelaskan alur 
rekam medis dan tugas-tugas yang dikerjakan sesuai lingkup bagian pada rekam medis. Informan satu sebagai informan kunci menjabarkan alur rekam medis secara keseluruhan serta tugas-tugas yang dikerjakan. Berikut adalah kutipan wawancara:

“... petugas pendaftaran itu menginput atau mengentri data pasien, memberikan penjelasan kepada pasien bila ada yang bertanya dan juga mengedukasi pasien bila ada pasien yang bertanya persyaratan-pesyaratan untuk kelengkapan peserta BPJS dan pasien tunai, mengkroscek jumlah kunjungan pasien dengan bagian loket keuangan. Lalu petugas kartu untuk di poli rawat jalan adalah dia mencari berkas rekam medis pasien, merapihkan dan menginput data pasien yang mendaftar online yang sebelumnya sudah ditumpuk oleh petugas pada shift malam, lalu sudah jam pelayanan dia harus mengambil berkas rekam medis dari poli rawat jalan lalu di kroscek antara berkas yang masuk dengan berkas yang keluar, setelah itu dirapihkan untuk dimasukan kembali ke raknya sesuai nomor-nomor urutan rekam medis. Lalu petugas pelaporan itu harus menginput berkas yang masuk setiap harinya dari hasil mengumpulkan hasil entri input data dari teman-teman di pendaftaran dan hasil kroscek antara di loket pendaftaran dan di pencari berkas, nanti teman-teman pelaporan ini harus menyediakan atau menyajikan data persatu bulan, laporan itu harus selesai dalam bentuk laporan untuk analisa, hasil analisa dari rekam medis, dipakai untuk manajeman sebagai bahan pertimbangan keputusan untuk mengambil suatu perencanaan. Kalau rawat inapnya sama juga bedanya kalau yang di rawat inap ini petugas kami ada 24 jam jadi ada yang bertugas malam." $\left(\boldsymbol{I}_{1}\right)$

\section{d) Motivasi}

Motivasi merupakan usaha untuk meningkatan kinerja. Motivasi diberikan oleh atasan agar tercapainya tujuan organisasi. Motivasi dilakukan dengan hubungan interaksi antara atasan dengan petugas, lingkungan kerja dan motivasi dari atasan. Untuk mengetahui motivasi yang dimiliki oleh petugas peneliti mengajukan pertanyaan yang berhubungan dengan hubungan interaksi antara petugas dengan atasannya, kondisi lingkungan kerja dan hal-hal yang membuat petugas termotivasi. Berdasarkan hasil wawancara yang dilakukan didapatkan hasil bahwa petugas mendapatkan motivasi positif dilihat dari hubungan interaksi dengan kepala rekam medis, lingkungan kerja dan hal-hal yang membuat petugas termotivasi, dapat dilihat dari kutipan wawancara berikut:

Kutipan wawancara mengenai hubungan interaksi:

“... sangat baik, terjalin sih komunikasinya." (I/2)

“... alhamdulillah, ya sesuai instruksi atasannya” (I 3 )

“... cukup koordinasi dan cukup baik.” (I4)

“... hubungan interaksinya ya, Kita punya WA grup jadi kita bisa berbicara setiap hari setiap saat setiap waktu di WA grup itu permasalahanpermasalahan yang ada di pekerjaan rekam medis bagian rekam medis. 
Selain itu juga kita biasanya mengadakan pertemuan rutin bulanan di rekam medis keseluruhannya datang disitu sambil ada sosialisasi atau edukasi lagi atau penjelasan-penjelasan mengenai seputaran pekerjaan rekam medis ataupun ada aturan-aturan baru dari BPJS ataupun ada kebijakan baru yang harus kita jalani itu di pertemuan bulanan. Komunikasi kita itu harus terjalan dengan baik, jadi komunikasinya baik." $\left(\boldsymbol{I}_{1}\right)$

Kutipan wawancara mengenai lingkungan kerja:

“... lingkungan kerja ya, harus expert sih kalau disini." (I $\left.\boldsymbol{I}_{2}\right)$

“...kalau kondisi lingkungan kerja ya alhamdulilah nyaman sih" (I $\left.\mathbf{I}_{3}\right)$

“...lingkungan kerja, kalau teman, temannya nyaman, kalau tempat kurang nyaman, kurang besar" (I $\left.\boldsymbol{I}_{4}\right)$

“... mungkin kalau di ranahnya rawat jalan kita masih lingkungan kerjanya masih agak enak ya jadi fokus pada satu tempat, pendaftaran, pelaporannya, berkas penyimpanan berkas rekam medis dan polinya masih satu lokasi jadi kalau untuk rawat jalan tidak ada masalah, baik ya. meskipun tempat penyimpanannya memang masih belum sempurna tapi lebih sudah lebih nyaman yang rawat jalan. Kalau dirawat inap, karena pendaftarannya jauh, terpisah satu gedung, nah kesulitannya adalah pas saat komunikasi suka terputus ada berkas untuk ke UGD atau ke ruang rawat inap dimana ruang rawat inap itu lokasinya sangat jauh di belakang gitu kita di depan itu aja. jadi kadang suka telat untuk mengantar berkas rekam medisnya. Tidak nyaman kali ya." (II)

Kutipan wawancara mengenai hal yang membuat petugas termovitasi:

“... termotivasi ya, bicara masalah termotivasi sebetulnya sih karna penempatan sesuai dengan jurusan terakhir, itu emang dapat masuk kualifikasinya di rekam medis. " (I 2$)$

“... semangat dan cita-cita ya, gitu aja sih." (I $\left.\mathbf{I}_{3}\right)$

“... motivasinya ya. bisa mendapatkan data yang akurat yang valid." (I

Kutipan wawancara mengenai movitasi yang diberikan kepala rekam medis terhadap petugas:

“... kalau motivasi setiap hari yang pasti dilakukan adalah sebisa mungkin pendekatan ya. Kadangkan kalau ada pasiennya banyak pasti orang yang melayani pasiennya juga rada-rada seperti jutek gitu ya, paling kita menyemangati bahwa bekerja itu adalah sebagian dari ibadah, seperti itu. Kalau yang untuk temen-temen disini adalah memberikan apresiasi seperti rasa terima kasih gitu kan yah dalam bentuk mensuport karna disini itu banyak yang bukan lulusan rekam medis, dan yang lulusan rekam medis hanya tiga, tapi kebutuhannya kan harusnya yang bertugas disini ada harus pendidikannya rekam medis, jadi mensuport untuk selalu memotivasi agar menambah ilmu lagi agar pelayanannya lebih baik sesuai dengan yang diharapkan gitu. Mendatangkan 
motivator untuk teman-teman disini agar bisa lebih punya inovasi lagi." $\left(\boldsymbol{I}_{1}\right)$

\section{Karakteristik Organisasi pada Rekam Medis}

a) Imbalan

Untuk Imbalan, peneliti menggali informasi mengenai reward yang diberikan, prestasi kerja yang mendapatkan reward dan tunjangan yang didapat oleh petugas. Berdasarkan hasil wawancara yang dilakukan, didapatkan hasil bahwa semua petugas rekam medis mendapatkan imbalan pada umumnya seperti gaji, jasa pelayanan dan reward. Dapat dilihat dari kutipan wawancara berikut.

Kutipan wawancara mengenai reward dan prestasi kerja:

"...salah satunya makan siang biasanya, terus ada juga kalau kita disini namanya itu TPP, TPP itu semacam bonus tiap perdua minggu diliatnya sih bukan dari pencapaian target rumah sakit cuman memang kalau dirumah sakit itu sebagian besar memang harus ada jasa itu apalagi dirumah sakit pemerintah, itu memang harus ada wajib. " (I $\left.\mathbf{I}_{2}\right)$

“...kalau di kartu kita belum ada sih yang prestasi untuk apa gitu, paling hanya untuk kerja sama dan kekompokan tim saja." (I $\left.\mathbf{I}_{3}\right)$

“... kalau dari kepalanya pernah sih pernah ada reward, pernah teladan eh teladan iya pokoknya pernah ada reward, buat karyawan pernah ada ya." (I4)

“... biasanya kita kasih ucapan-ucapan terimakasih terus reward itu kan sesuatu yang baik ya yang sudah bekerja dengan baik disini sesuai dengan aturan SPO ada. kita rewardnya adalah misalnya kita kumpul dalam bareng-bareng, bulanan itu ada yang kita kasih hadiah tapi dia harus jawab dulu pertanyaan seperti itu ya. reward biasanya reward pada prestasi khusus misalnya reward yang kita berikan selain tadi hadiah kecil untuk petugas yang berprestasi ya, ini untuk petugas yang berprestasi kita mengajukan untuk kalau yang untuk non pendidikan rekam medis, apalagi PNS gitu ya, kami biasanya memberikan promosi, atau memberikan kalau untuk yang PNS diberikan kesempatan untuk pendidikan untuk yang non rekam medis itu di berikan kemarin tuh bantuan, bantuan untuk bersekolah tapi pada jurusan rekam medis gitu. teman-teman yang sudah rekam medis, di arahkan untuk mengambil sekolah lagi tapi pada bagiannya rekam medis." (II)

Kutipan wawancara mengenai tunjangan:

“...Salah satunya TPP yang kedua gaji 13 terus samaa bonus dari masingmasing kepala unit." (I/2)

“...hanya gaji aja sama jasa pelayanan.” (I 3 )

“...Paling hanya jasa pelayanan, selain gaji jasa pelayanan aja..” (I/)

“...kalau tunjangan, kita cuman dapat tunjangan jasa pelayanan, iya.” (II)

\section{b) Pelatihan}

Berdasarkan hasil wawancara yang dilakukan didapatkan hasil bahwa informan utama telah mengikuti pelatihan, dan menurut 
informan seluruh petugas dapat mengikuti pelatihan yang diadakan rekam medis dan tidak ada kriteria khusus yang di butuhkan untuk melakukan pelatihan. Berikut adalah hasil wawancara:

“...damkar, salah satunya damkar terus seminar samacam seminar kesehatan masih banyak sih semua seminarseminar itu yang masuknya ke katagori kesehatan. kalau kriteria engga, soalnya memang disini semua petugas wajib dapat ilmu itu. kalau untuk yang apa, yang SMA kali ya, yang SMA ikut pelatihan dasar rekam medis kalau yang belum pendidikan rekam medis." (I)

“... pelatihan ada, waktu itu pelatihan rekam medis. engga ada kriteria sih, paling hanya seluruh petugas rekam medis aja." (I $\left.\mathbf{I}_{\mathbf{3}}\right)$

"...pelatihan rekan medis. dulu tentang koding sih, dulu pernah tapi dulu banget." (I4)

“...pelatihan rekam medis dasar untuk semua petugas rekam medis yang sudah rekam medis maupun non rekam medis. Terus pelatihan SIM RS, waktu itu kita kerja sama dengan teman-teman di UI di bagian IT nya. Jadi kita pernah mendatangkan narasumber dari UI untuk melatih kita, pelatihan-pelatihan SIM RS untuk teman- teman di rekam medis. tidak ada kriteria karna kriterianya hanya satu untuk petugas yang memang bekerja di lingkungan rekam medis, karena kami yang tadi saya awal bicarakan bahwa kita tidak semuanya disini lulusan rekam medis. Jadi semuanya diharuskan untuk tau." (I)

\section{c) Struktur Organisasi}

Berdasarkan telaah dokumen yang dilakukan didapatkan struktur organisasi Rekam Medis, sebagai berikut:

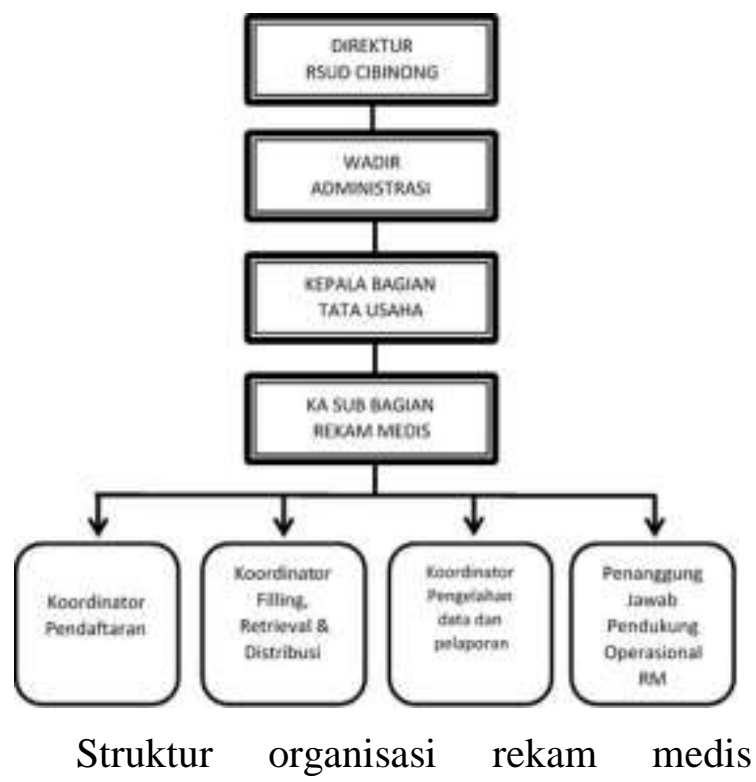
memiliki garis komando sehingga seluruh petugas Rekam Medis bertanggung jawab kepada setiap Koordinator bagian masingmasing, seluruh Koordinator dan Penanggung jawab pendukung operasional bertanggung jawab kepada Kepala Sub Bagian Rekam Medis, Kepala Sub Bagian Rekam Medis bertanggung jawab kepada Kepala Bagian Tata Usaha, Kepala Bagian Tata Usaha bertanggung jawab kepada Wakil Direktur Administrasi, dan Wakil Direktur Administrasi bertanggung jawab kepada Direktur RSUD Cibinong.

\section{d) Visi Misi}

Berdasarkan telaah dokumen yang dilakukan visi dan misi rekam medis mengikuti visi misi RSUD Cibinong, yaitu sebagai berikut:

Visi: "RSUD Cibinong sebagai Rumah Sakit yang diandalkan dan dipercaya masyarakat" 
Misi:

1. Meningkatkan performa Rumah Sakit

2. Meningkatkan kualitas sumber daya manusia

3. Meningkatkan mutu pelayanan Rumah Sakit

4. Mengembangkan program pendidikan dan pelatihan

5. Menciptakan Rumah Sakit berwawasan lingkungan (Green Hospital)

\section{e) Kepemimpinan}

Untuk menjalankan organisasi dibutuhkan pemimpin yang memiliki kepemimpinan yang berpengaruh terhadap petugas, sehingga dapat tercapainya tujuan organisasi. Hal yang dilakukan dapat proses monitoring, pemberian arahan, tindakan evaluasi dan sikap atasan terhadap tugas petugas serta cara atasan meningkat kinerja. Berdasarkan hasil wawancara dengan semua informan didapatkan hasil bahwa kepemimpinan yang terdapat di bagian rekam medis sudah cukup baik dilihat dari hal-hal yang dilakukan untuk memonitoring petugas, pemberian arahan, melakukan evaluasi oleh kepala rekam medis serta sikap kepala rekam medis sebagai seorang pemimpin.

Kutipan wawancara mengenai proses monitoring:

“...biasaya kalau untuk petugas kepala unit rekam medis itu. melihat dari hasil recount bulanan terus dilihat dari hasil seberapa banyak perubahan dari sistem yang di perbaharui dari vendor-vendor kita sebagai apa ya, salah satuu bentuk perubahan mungkin ya bisa dikatakan seperti itu." (I $\left.\boldsymbol{I}_{2}\right)$ “...iya itu selalu selalu, iya istilahnya adaa kalau seumpamanya ada masalah atau apa pasti pimpinan kita monitor." (I)

“...rapat terus analisa dari setiap laporan yang ada” (I $\mathbf{I}_{4}$

“... kita punya eleman-eleman penilaian ya, sesuai dengan tupoksinya masing-masing itu dibuatkan dalam satu apa kaya tabel gitu. jadi elemen penilaian itu dituangkan misalnya bagian kartu dia tugasnya apa saja di tuangkan pada eleman penilaian itu. lalu ada disitu kita pake ceklis, kalau tidak kita silang kalau iya kita ceklis." $\left(I_{1}\right)$

Kutipan wawancara mengenai Pemberian arahan:

“... Iya." $\left(\boldsymbol{I}_{2}\right)$

“... Pasti, pasti memberikan arahan.”

(I)

“...memberi" $\left(\mathbf{I}_{4}\right)$

“...kalau petugas, arahan itu setiap saat. setiap hari memang selalu diingatkan karena tadi kita bekerja sebagai pelayanan masyarakat, jadi harus selalu diingatkan setiap hari dan bila ada aturan baru atau regulasi baru dari rumah sakit sendiri, dari pemda atau dari BPJS yang saat ini pesertanya terbanyak maka selalu disampaikan karna kalau tidak disampaikan kita salah nanti, jadi tidak tidak sesuai dengan aturannya seperti itu." (I $\left.\boldsymbol{I}_{1}\right)$

Kutipan wawancara mengenai evaluasi yang dilakukan: 
“... Kalau untuk evaluasi pasti, satu bulan sekali itu pasti iya. Bagus, sangat baik." (I $\boldsymbol{I}_{2}$

“... iya, kita selalu setiap bulan atau setiap minggu melakukan evaluasi, bila ada hambatan atau halangan pasti kita lapor ke pimpinan." (I $\left.\mathbf{I}_{\mathbf{3}}\right)$

“... Iya." (I4)

"...evaluasi itu sama dengan monitoring ya. Disetiap bulan ada evaluasi dilihat dari kerjaannya, disiplinnya (absensi) juga. Satu bulan itu kita mengevaluasi masalah, permasalahan terbanyak dimana saja, misalnya permasalahan itu tidak selesai ditingkatnya maka hasil evaluasi dari permasalahan ini kita naikan lagi ke atas, ke jajarannya kepala bagian." (II)

Kutipan wawancara dengan kepala rekam medis mengenai cara meningkatkan kinerja petugas:

“... dilihat dari hasil evaluasi atau monitoring, menilai orangnya satu-satu dalam sebulan dan dilihat bagian mana yang memiliki banyak masalah. Dari situ kita melihat keluhan-keluhan atau masukan-masukan dari bagian lain seperti bagian poli rawat jalan dan instalasi-instalasi yang berkaitan dangan rekam medis, sebagai catatan untuk nanti sebagai bahan evaluasi hasil kerja rekam medis.melakukan misalnya selama ini permasalahan pada pelayanan pendaftaran, temanteman dari pendaftaran ada yang salah nih terlihat dari input data pasien yang terinput di SIM RS sudah lengkap atau belum. Jika dia tidak menginput berarti data yang keluar dari laporan juga tidak bagus hasilnya maka saya akan melakukan koordinasi dengan bagian terkait." (II)

Kutipan wawancara dengan petugas rekam medis mengenai gambaran sikap kepala rekam medis sebagai pemimpin:

“... bagus, sangat baik.” (I 2$)$

“... alhamdulillah berjiwa pemimpin,

iya." (I3)

“... cukup baik..” (I4)

\section{Karakteristik Pekerjaan pada Rekam Medis}

1) Deskripsi Pekerjaan

\section{a. Petugas Pendaftaran}

\begin{tabular}{|c|c|}
\hline $\begin{array}{l}\text { Nama } \\
\text { Jabatan }\end{array}$ & $\begin{array}{l}\text { Pelaksana Pendaftaran Pasien Rawat Jalan, } \\
\text { IGD, dan Rawat Inap }\end{array}$ \\
\hline $\begin{array}{l}\text { Tugas } \\
\text { Pokok }\end{array}$ & $\begin{array}{l}\text { 1. Melaksanakan kegiatan pendaftaran } \\
\text { pasien rawat jalan, IGD, dan pasien } \\
\text { rawat inap. } \\
\text { 2. Memberikan pelayanan pendaftaran } \\
\text { pasien rawat jalan, IGD, rawat inap. } \\
\text { 3. Melaksanakan input data pasien rawat } \\
\text { jalan, IGD, dan rawat inap. }\end{array}$ \\
\hline $\begin{array}{l}\text { Uraian } \\
\text { Tugas }\end{array}$ & $\begin{array}{l}\text { 1. Mendaftarkan pasien yang akan berobat } \\
\text { rawat jalan, IGD dan rawat inap. } \\
\text { 2. Mengentri data identitas dan data sosial } \\
\text { pasien ke SIM RS. } \\
\text { 3. Mencetak lembar ringkasan masuk dan } \\
\text { keluar pasien rawat inap. } \\
\text { 4. Membuat jaminan SEP untuk pasien } \\
\text { RPJS. } \\
\text { 5. Memberikan informasi ti cara } \\
\text { pendaftaran, informasi tempat tidur } \\
\text { kosong, general consent. } \\
\text { 6. Membuat set formulir rawat inap. }\end{array}$ \\
\hline
\end{tabular}

b. Pelaksana Filling, Retrieval, dan Distribusi Berkas Rekam Medis

\begin{tabular}{|c|c|}
\hline $\begin{array}{l}\text { Nama } \\
\text { Jabatan }\end{array}$ & $\begin{array}{l}\text { Pelaksana Filling, Retrieval, dan Distribusi } \\
\text { Berkas Rekam Medis }\end{array}$ \\
\hline $\begin{array}{l}\text { Tugas } \\
\text { Pokok }\end{array}$ & $\begin{array}{l}\text { 1. Mengevaluasi dan menganalisa } \\
\text { ketepatandan dalam } \\
\text { pengambilan dan pendistribusian berkas } \\
\text { rekam medis, } \\
\text { 2. Memonotoring pelaksanaan pelayanan } \\
\text { peminjaman dan pengambilan bekas } \\
\text { rekam medis. } \\
\text { 3. Menyediakan kebutuhan ATK dan } \\
\text { formulir-formulir berkas rekam medis } \\
\text { rawat jalan. }\end{array}$ \\
\hline
\end{tabular}




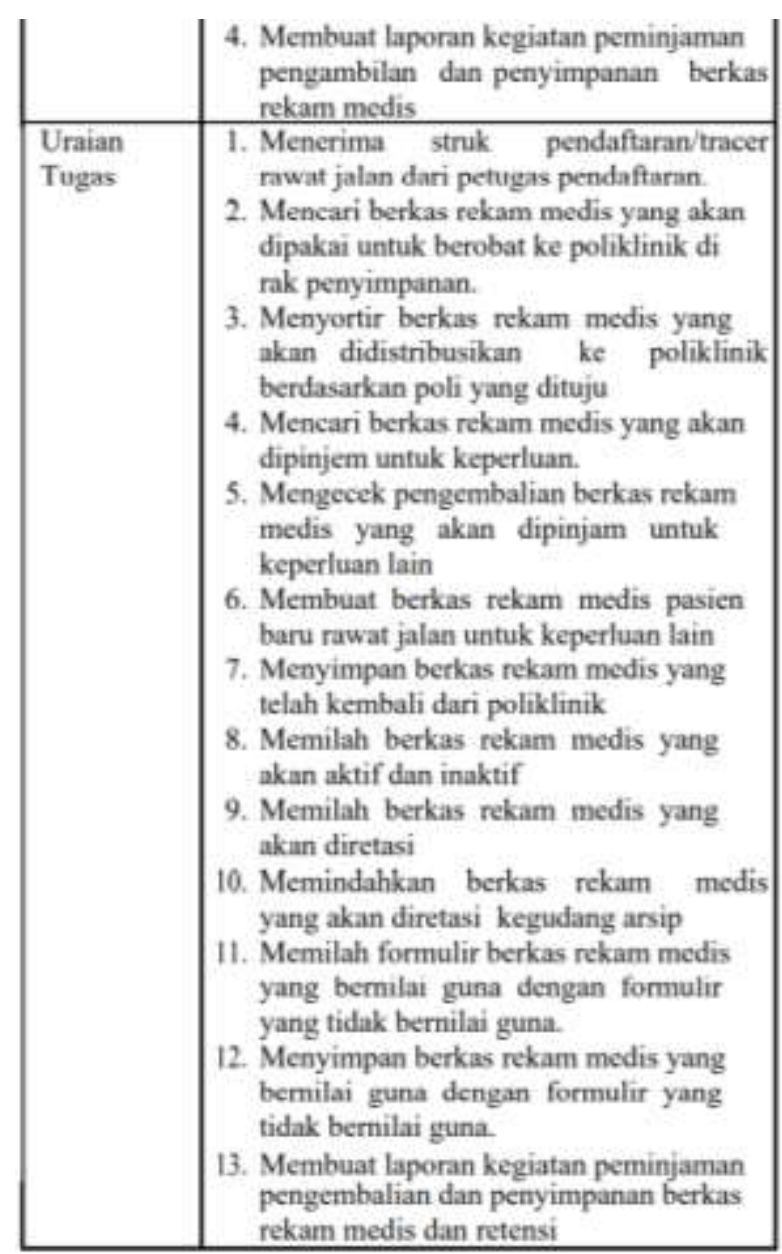

c. Pengolahan Data dan Pelaporan

\begin{tabular}{|c|c|}
\hline $\begin{array}{l}\text { Nama } \\
\text { Jabatan }\end{array}$ & $\begin{array}{l}\text { Pelaksana Filling, Retrieval, dan Distribusi } \\
\text { Berkas Rekam Medis }\end{array}$ \\
\hline $\begin{array}{l}\text { Tugas } \\
\text { Pokok }\end{array}$ & $\begin{array}{l}\text { 1. Assembling/merakit berkas rekam medis } \\
\text { yang kembali dari ruangan. } \\
\text { 2. Koding dan indeksing berkas rekam } \\
\text { medis } \\
\text { 3. Melakukan analisa kelengkapan berkas } \\
\text { rekam medis yang kembali dari ruangan } \\
\text { 4. Membuat laporan intemal dan eksternal } \\
\text { RS }\end{array}$ \\
\hline $\begin{array}{l}\text { Uraian } \\
\text { Tugas }\end{array}$ & $\begin{array}{l}\text { 1. Menerima berkas rekam medis pasien } \\
\text { pulang dari ruangan. } \\
\text { 2. Mengentri dikomputer berkas rekam } \\
\text { medis pasien pulang dari ruangan. } \\
\text { 3. Melakukan pengecekan kelengkapan } \\
\text { berkas rekam medis. } \\
\text { 4. Menyusun berkas rekam medis } \\
\text { berdasarkan urutan nomor rekam medis. } \\
\text { 5. Menerima formulir klaim asuransi } \\
\text { kedokter yang merawat/menerangkan. } \\
\text { 6. Menyediakan berkas rekam medis untuk } \\
\text { pengisian formulir klaim asuransi dan } \\
\text { surat keterangan medis lainnya. } \\
\text { 7. Mengajukan formulir klaim asuransi ke } \\
\text { dokter yang merawat/menerangkan. } \\
\text { 8. Mengembalikan berkas rekam medis } \\
\text { yang tidak lengkap kepelaksana } \\
\text { pengkodean dan pengindekan. }\end{array}$ \\
\hline
\end{tabular}

9. Menyerahkan berkas rekam medis yang sudah lengkap ke pelaksana pengkodean dan pengindekan.

10. Menerima dan menginput sensus harian rawat inap

11. Mengelolah rekapitulasi sensus harian rawat inap menjadi angka indikator RS

12. Mengkoding diagnosia rawat jalan dan rawat inap

13. Membuat indeksing penyakit, kematian nama dokter

14. Mengerjakan laporan internal dan eksternal

\section{2) Jadwal Pekerjaan}

Berdasarkan hasil observasi terhadap jadwal pekerjaan didapatkan semua petugas rekam medis diwajibkan datang lebih pagi sebelum dimulai aktifitas pekerjaan. Bagian pendaftaran sudah mulai datang jam 6.10 untuk mempersiapkan pedaftaran pasien rawat jalan yang dimulai pada pukul 07.00, hari senin sampai kamis pengambilan nomor antrian di tutup jam 11.00 jumat dan sabtu tutup 10.00, Penyelesaian tugas sesuai dengan jumlah pasien yang datang. Waktu istirahat siang dari jam 12.00-13.00 setelah seluruh pasien mendapatkan pelayanan petugas melakukan assembling untuk berkas rawat inap dan IGD, petugas dapat pulang jam 2 jika sudah tidak ada lagi yang dikerjakan. Bagian kartu (pengambilan dan pendistribusian berkas) Petugas memulai pekerjaannya ketika pelayanan pasien dibuka. Bagian kartu merupakan pelayanan 24 jam sehingga di bagi menjadi 3 shift. Shift 1 dari jam 07.00 sampai 14.00 , shift 2 dari jam 14.00 sampai jam 21.00, dan shift 3 dari jam 21.00 sampai 07.00. Bagian pelaporan, petugas melakukan apel setiap pagi pada jam 07.30. Pekerjaan dimulai jam 8 , istirahat siang selama satu jam dari jam 12.00 sampai jam 13.00, masuk kembali dan pulang jam 16.00. Petugas bagian pendaftaran dan kartu tidak mengikuti apel karena melakukan pelayanan langsung kepada pasien.

Berdasarkan hasil wawancara yang dilakukan didapatkan hasil bahwa jadwal 
pekerjaan yang di dapat sesuai dengan jam pelayanan dan waktu yang telah ditetapkan oleh RSUD Cibinong. Dilihat dari kutipan wawancara berikut, Kutipan wawancara mengenai jadwal pekerjaan petugas dari datang hingga pulang:

“... Kalau untuk eee... mulai nomor antrian itu dimulai kita enam lewat sepuluh tapi kalau untuk mulai pendaftaran pembukaan sistem itu enam tiga puluh sampai jam sebelas untuk senin sampai kamis, untuk jumat dan sabtu itu sampai jam sepuluh" (I2)

“... ya, jadwal kita sesuai pelayanan, ya kalau misalnya pelayanan belum selesai kita masih tetap terus. dari jam tujuh sampai jam dua" (I $\left.\mathbf{I}_{3}\right)$

“... dari jam setengah delapan sampai jam empat” (I)

“...Sesuai dengan aturan. Kalau aturan kan jam 07.25 itu sudah masuk apel ya. Tapi karna kita tidak bisa mengikuti kaidah itu kita harus pagi. Pasien itu sudah datang dari subuh dia sudah datang jam 6 sudah mulai ke pasien. Kalau jadwal kerja itu tiap bagiannya tidak sama. Karna dilihat kebutuhan yang ada dilapangan." (I $\left.\boldsymbol{I}_{\boldsymbol{1}}\right)$

Kutipan wawancara mengenai ketepatan waktu dalam menyelesaikan tugas:

“...tergantung total pasien perhari, iya kalau untuk jam pendaftaran kita batasi

\section{Pembahasan}

\section{Kinerja Petugas Rekam Medis}

Berdasarkan hasil penelitian kinerja petugas sudah cukup baik, bahwa petugas mengerjakan tugasnya sesuai dengan sampai jam 11 maksimal tapi kalau untuk pendaftaran pasien itu sesuai nomor yang ada" (I,

“...oiya, kitaa jadwalnya sampai jam 2 seumpama ada jam masih ada kerjaan kita masih kita kerjaan karna tapi lewat dari jam itu kita kerjakan. Karna disini kita 24 jam, rekam medis 24 jam jadi eumpama ada kelebihan jam kerja atau kaya gimana entar yang siang yang nerusin pekerjaan" (I $\left.\mathbf{I}_{3}\right)$

“...kadang-kadang kalau kalau engga ada rapat atau apa gitu tepat waktu bisa, tapi kalau misalnya ada banyak rapat atau apa biasanya keteter agakagak keteter" (I $\left.\mathbf{I}_{4}\right)$

“...Kalau selesai pasti ada beberapa yang belum sempurna selesainya ya. Karna tadi kita kan bukan istilahnya pasien, mungkin kalau pasien pasti selesai pas jam 2 selesai karna memang pelayanan selesai jam 2. Tapi yang namanya kumpulkan berkas rekam medis itu tidak bisa sampai teng jam 2 dia harus pulang petugas-petugas kami itu untuk kartu misalnya tadi ya. Jadi sesuai kebutuhan disini itu harus pulang jam 5 karna sampai ditunggu disini tuh sampai berkas rekam medis yang ada di poli masuk ke kita, ke rekam medis bisa sama tidak sesuai dengan yang ditetapkan." (II)

tupoksinya masing-masing seperti di bagian pendaftaran, kartu dan pelaporan. Hasil kerja petugas sesuai dengan pembagian tugas yang terdapat pada tupoksi, menurut petugas 
pendaftaran dan petugas kartu hasil kerja yang dikerjakan sesuai dengan harapan dan menurut petugas pelaporan hasil kerja belum sesuai dengan yang diharapkan. Dalam menilai kinerja petugas dilihat dari datang tepat waktu dan hasil dari proses yang dilakukan sesuai dengan tupoksinya masingmasing. Namun dalam pencapaian SPM Rekam medis yang sudah tercapai terdapat kendala dalam pencatatan waktu pendistribusian berkas rekam medis rawat jalan, sehingga pencatatan tersebut tidak sesuai definisi operasional SPM tersebut dimana waktu penyediaan dokumen rekam medis mulai dari pasien mendaftar sampai rekam medis disediakan/ditemukan oleh petugas. Petugas hanya melakukan pencatatan waktu pada pencarian berkas. Dan kelengkapan pengisian berkas rekam medis dan Informed Consent yang belum mencapai $100 \%$.

Menurut Sumampouw, pelayanan rekam medis yang baik dan bermutu tercermin dari pelayanan yang ramah, cepat, serta nyaman. Pelayanan rekam medis rawat jalan dimulai dari tempat pendaftaran pasien sampai memperoleh dokumen rekam medis yang akan digunakan untuk mendapat pelayanan kesehatan. Berdasarkan standar penyediaan dokumen rekam medis pelayanan rawat jalan adalah 10 menit. Penelitian yang dilakukan Anggraini (2001) tentang analisis pelaksana peraturan perundang-undangan rekam medis instalasi rawat inap di RSUP Persahabatan sebagai alat bukti dalam tuntutan hukum, menyimpulkan bahwa sebagian besar tenaga kesehatan sebenarnya mengetahui ada peraturan perundangundangan rekam medis namun isinya belum begitu dipahami sehingga penerapan di lapangan berdasarkan pengalaman selama dan masih ada ketentuan yang belum dapat terlaksana dengan baik. Salah satu kegunaan rekam medis adalah aspek legal dan dapat dijadikan sebagai alat bukti bagi dokter dan perawat yang terkena tuntutan kelalaian apabila rekam medis diisi secara lengkap, akurat, tepat waktu dan memenuhi persyaratan hukum.

\section{Karakteristik Individu Petugas Rekam Medis}

Karakteristik Individu Petugas Rekam medis dilihat dari kemampuan, keterampilan, pengetahuan, dan motivasi yang dimiliki oleh petugas.

Menurut Robbin (2006) kemampuan kerja menunjukan kecakapan seseorang seperti keterampilan. Kemampuan berhubungan erat dengan kemampuan fisik dan mental yang dimiliki orang untuk melaksanakan pekerjaan. Ketidakberadaan hal seperti ini dapat mempengaruhi peningkatan kinerja karyawan.

Berdasarkan hasil penelitian diketahui bahwa petugas memiliki kemampuan yang dibutuhkan dalam melaksanakan pekerjaannya seperti mampu mengoperasikan komputer, mampu berkomunikasi dengan sesama petugas yang lain, mampu mengerjakan tugas dengan cepat dan teliti. Setiap bagian di rekam medis memiliki keterampilan yang berbeda-beda seperti di bagian pendaftaran keterampilan petugas dalam menginput data pasien sesuai dengan kolom yang tersedia, di bagian kartu petugas harus dapat bergerak dengan cepat dalam melakukan pencarian berkas dan menghafal nomor-nomor rekam medis untuk mempermudah pencarian, dan dibagian pelaporan dapat menggunakan aplikasi dalam komputer untuk melakukan pengolahan data.

Keterampilan merupakan kemampuan seseorang untuk melakukan suatu aktivitas atau pekerjaan. Lebih lanjut tentang keterampilan Dunnett's dalam lian (2013) skill adalah sebagai kapasitas yang dibutuhkan untuk melaksanakan suatu 
rangkaian tugas yang berkembang dari hasil pelatihan dan pengalaman. Keahlian seseorang tercermin dengan seberapa baik seseorang dalam melaksanakan suatu kegiatan yang spesifik, seperti mengoprasikan suatu peralatan (fasilitas ruangan), berkomunikasi efektif atau mengimplementasikan suatu strategi bisnis (Arisandy, 2015).

Berdasarkan hasil penelitian diketahui bahwa petugas membutuhkan keterampilan yang dapat menunjang proses bekerja agar melancarkan pekerjaan. Setiap bagian memiliki keterampilan yang berbeda. Mulai dari keterampilan menggunakan komputer, memiliki public speaking yang baik, tangkas dan cepat dalam melaksanakan tugas.

Pengetahuan adalah hasil penginderaan manusia atau hasil tahu seseorang terhadap objek melalui indera yang dimilikinya (mata, hidung, telinga, dan sebagainya).

Dengan sendirinya, pada waktu penginderaan sampai menghasilkan pengetahuan tersebut sangat besar pengetahuan tersebut sangat dipengaruhi oleh intensitas perhatian dan persepsi terhadap objek. Sebagian besar pengetahuan seseorang diperoleh melaui indera pendengaran dan indera pengelihatan (Notoatmojo, 2005 dalam Arbain, 2011).

Berdasarkan hasil penelitian diketahui bahwa petugas dapat menjelaskan bagaimana alur berkas rekam medis dan tugas yang dikerjakan pada setiap bagian direkam medis. Kepala rekam medis menjelaskan secara keseluruhan mengenai alur berkas rekam medis bahwa "alur berkas rekam medis dimulai dari pasien mengambil nomor antrian lalu dia datang ke loket pendaftaran, diloket pendaftaran identitas sampai keperluan pengobatan di input oleh petugas pendaftaran yang kemudian akan keluar tracer, tracer di cetak olah dipetugas kartu untuk mempermudah dalam pencarian berkas, petugas kartu akan mencatat nomor rekam medis dengan tujuan poli sebagai cacatan riwayat pendistribusian berkas, berkas yang sudah di ambil diserahkan kepada kurir untuk selanjutnya di letakan di meja dokter, setelah selesai pelayanan berkas tersebut diambil oleh kurir dari ruangan poli lalu di cek oleh petugas pelaporan setelah itu diletakan kembali di rak untuk berkas yang sudah lengkap, sebelum tanggal 30 petugas pelaporan harus menyediakan atau menyajikan data persatu bulan, petugas pelaporan menganalisa untuk memberikan hasil analisa dari rekam medis yang akan dipakai untuk manajeman sebagai bahan pertimbangan dan keputusan dalam mengambil suatu perencanaan."

Motivasi kerja berarti dorongan atau kehendak seseorang untuk melaksanakan tindakan atau kegiatan dalam lingkup tugastugas yang merupakan pekerjaan atau jabatan di lingkungan sebuah organisasi. Motivasi yang tinggi dapat meningkatkan dan menumbuhkan semangat kerja karyawan dengan demikian akan tercapai kinerja karyawan yang tinggi sedang semakin tinggi kualitas lingkungan kerja seseorang akan meningkatkan motivasi kerja orang tersebut (Lubis, 2012 dalam Yulius, 2014).

Berdasarkan hasil penelitian dapat diketahui bahwa motivasi terbentuk dari dalam dan luar individu. Motivasi bekerja yang dimiliki petugas yaitu untuk bekerja, mencapai cita-cita dan kesesuaian dengan pendidikan terakhir yang ditempuh. Selain motivasi dari dalam diri individu terdapat motivasi yang dapat muncul dari interaksi kepada atasan, lingkungan kerja dan usaha pemimpin memberikan motivasi kepada petugas. Interaksi antara petugas dengan kepala rekam medis cukup baik, lingkungan kerja cukup nyaman namun pada bagian kartu ruangan yang tersedia untuk penyimpanan berkas kurang luas karena menyimpan berkas yang sangat banyak sehingga berkas yang 
tidak cukup dirak diletakan dilantai, dan petugas mendapatkan motivasi dari kepala rekam untuk meningkatkan kinerja di setiap bagian.

\section{Karakteristik Organisasi pada Rekam medis}

Menurut Mulyono (2012),

kepemimpinan berperan sangat penting dalam manajemen karena unsur manusia merupakan variabel yang teramat penting dalam organisasi. Manajer dan supervisi memiliki tanggung jawab terhadap kegiatan-kegiatan organisasi terdiri dari para manajer, para supervisor, dan para pelaksana. Manusia memiliki karakteristik yang berbeda-beda mempunyai kepentingan masing-masing, yang bahkan saling berbeda dan berakibat terjadi konflik. Perbedaan kepentingan tidak hanya antar individu di dalam organisasi, tetapi juga antara individu dengan organisasi di mana individu tersebut berada. Sangat mungkin bahwa perbedaan hanya dalam hal yang sederhana, namun ada kalanya terjadi perbedaan yang cukup tajam. Tanpa kepemimpinan yang baik, hal-hal yang telah ditetapkan dalam perencanaan dan pengorganisasian tidak akan dapat direalisasikan.

Berdasarkan hasil penelitian dapat diketahui bahwa kepemimpinan yang berada direkam medis cukup baik. Dilihat dari pandangan petugas kepada kepala rekam medis yang selalu memonitoring dan memberikan arahan baik berupa rapat bulanan atau memonitoring langsung ke lapangan jika terjadi suatu masalah. Kepala rekam medis menjelaskan bahwa monitoring yang dilakukan sesuai dengan eleman-eleman penilaiannya sesuai dengan tupoksinya, untuk arahan dilakukan setiap saat dan bila ada aturan baru atau regulasi baru dari rumah sakit, pemda atau dari BPJS selalu diarahkan agar tidak terjadi kesalahan dalam pelayanan.
Imbalan merupakan sesuatu yang diterima oleh personel sebagai gaji, insentif dan tunjangan dimana penyesuaian ketiga hal tersebut sering digunakan sebagai evaluasi kinerja serta untuk memperbaiki kinerja personel (Ilyas, 2007 dalam Tsauri, 2015). Swansburg (1999) dalam Rego (2014) menyatakan bahwa pemberian imbalan atas pencapaian pekerjan akan membantu pegawai berkinerja lebih dan membuat lebih loyal terhadap organisasi. Pemberian imbalan memberikan dampak positif terhadap perilaku karyawan, menimbulkan kepuasan kerja bagi karyawan, memberikan dampak positif terhadap kemampuan organisasi, mampu menghasilkan tujuan yang telah dirancang dari mempertahankan lebih banyak karyawan yang mampu bekerja dengan prestasi tinggi.

Berdasarkan hasil penelitian dapat diketahui bahwa imbalan diketahui bahwa bahwa setiap petugas mendapatkan tunjangan berupa gaji, jasa pelayanan, dan reward berupa ucapan terima kasih dan hadiah jika mengadakan kuis pada rapat bulanan untuk meningkatkan rasa kekeluargaan. Untuk petugas yang memiliki prestasi kerja kepala rekam medis mengajukan kepada atas, untuk yang non pendidikan rekam medis dan PNS untuk diberikan promosi atau diberikan bantuan untuk melanjutkan pendidikan tetapi kearah untuk rekam medis.

Visi menggambarkan tujuan atau kondisi dimasa depan yang ingin dicapai. Visi memberikan gambaran yang jelas dimasa mendatang yang bisa dilihat oleh para stakeholder. Misi perusahaan adalah sebuah ekspresi dari ambisi untuk mengembangkan perusahaan. Pernyataan misi yang efektif adalah mendefinisikan bisnis dari tiap grup kecil dalam organisasi. Pernyataan tersebut akan membuat para karyawan lebih mengerti mengenai tujuan mereka. Berdasarkan telaah dokumen bagian rekam medis memiliki visi misi sama dengan visi misi RSUD Cibinong. 
Sub bagian rekam medis mengerjakan misi rumah sakit untuk mencapai visi Rumah Sakit Struktur organisasi garis menganut konsep yang bersifat vertical, yaitu dimana setiap perintah, kebijakan, aturan dan petunjuk penugasan bersumber dari atasan ke bawahan. Organisasi garis (hierarki) yang dipelori $\mathrm{H}$. Fayol merupakan struktur organisasi yang tertua. Dari konsepnya menunjukan bahwa pada organisasi ini penanggung jawab keputusan adalah pimpinan, dan penanganggung jawab tertinggi adalah pimpinan yang tertinggi, dan seterusnya. Kondisi organisasi seperti ini dianggap sangat simple dan mudah dalam memahaminya, terutama jika ingin mengecek kesalahan atau beberapa hambatan yang terjadi dan siapa yang bertanggung jawab. (Fahmi, 2012)

Berdasarkan telaah dokumen struktur organisasi yang dimiliki oleh sub bagian rekam medis memiliki bentuk organisasi garis dan memiliki garis komando sehingga seluruh petugas Rekam Medis bertanggung jawab kepada setiap Koordinator bagian masingmasing, seluruh Koordinator dan Penanggung jawab pendukung operasional bertanggung jawab kepada Kepala Sub Bagian Rekam Medis, Kepala Sub Bagian Rekam Medis bertanggung jawab kepada Kepala Bagian Tata Usaha, Kepala Bagian Tata Usaha bertanggung jawab kepada Wakil Direktur Administrasi, dan Wakil Direktur Administrasi bertanggung jawab kepada Direktur RSUD Cibinong.

\section{Karakteristik Pekerjaan pada Rekam Medis}

Pada penelitian yang dilakukan oleh mustikawati yang berjudul "Pengaruh Job Deskription terhadap kinerja karyawan departemen security di PT Wilmar Nabati Indonesia-Gresik" mendapatkan hasil bahwa job description (deskripsi pekerjaan) berpengaruh positif terhadap kinerja. Hal ini berdasarkan atas survey, dengan adanya job description maka akan membantu mengarahkan pekerjaan menjadi teratur. Sehingga langkah-langkah yang diambil dalam melakukan pekerjaan akan lebih jelas dan gambling (Mustikawati, 2014). Berdasarkan hasil penelitian diketahui bahwa deskripsi pekerjaan pada bagian rekam medis memiliki deskriptif pekerjaan yang jelas dilihat dari penjabaran tugas pokok dan fungsi masing-masing bagian. Sehingga petugas dapat lebih terarah dalam mengerjakan pekerjaannya.

Dalam undang-undang no 13 tahun 2003 tentang ketenagakerjaan untuk petugas yang bekerja 6 hari dalam seminggu, memiliki jam kerja 40 jam dalam 1 minggu. Sedangkan untuk petugas dengan 5 hari kerja memiliki jam kerja 40 jam kerja dalam 1 minggu dan kewajiban bekerja 8 jam dalam 1 hari. Berdasarkan hasil penelitian diketahui bahwa jadwal pekerjaan pada bagian rekam medis sesuai dengan tupoksi yang dilakukan. Petugas pendaftaran memiliki 6 hari kerja dalam semingggu, memulai pekerjaannya sebelum pendaftaran dibuka yaitu pukul 06.00 pagi dan tutup pendaftaran pukul 14.00 siang, setelah selesai melayani pasien di pendaftaran petugas melakukan assembling berkas untuk rawat jalan maupun rawat inap setelah selesai assabling petugas dapat pulang. Untuk petugas kartu memiliki 6 hari kerja diberlakukan shift kerja karena untuk pencarian berkas tidak hanya untuk rawat jalan tetapi untuk pasien IGD yang jam operasionalnya 24 jam, untuk shift pertama pagi sampai siang dari jam 7 pagi sampai jam 2 siang. Untuk petugas pelaporan memiliki 5 hari kerja, pekerjaan dimulai pukul 08.00 pagi sampai 16.00 sore. 


\section{Kesimpulan}

Berdasarkan hasil dan pembahasan penelitian dapat ditarik kesimpulan sebagai berikut:

1. Petugas rekam medis memiliki kinerja yang cukup baik, namun masih terdapat beberapa kendala yang dihadapi petugas seperti perhitungan waktu penyediaan berkas rekam medis tidak sesuai definisi operasional dalam SPM Rekam medis, keterlambatan pengembalian berkas rekam medis setelah pelayanan, dan ketidaklengkapan pengisian berkas setelah 24 jam pelayanan dan pengisian informed consent.

2. Gambaran karakteristik individu petugas rekam medis yaitu petugas memiliki kemampuan dan keterampilan yang sesuai dengan penempatan bagian dan pekerjaan yang dilakukan. Petugas memiliki pengetahuan terhadap alur rekam medis dan tugas-tugas yang dikerjakan sesuai tupoksi. Motivasi petugas dipengaruhi oleh hubungan interaksi yang baik antara petugas dengan atasannya, suasana lingkungan kerja yang cukup nyaman, keinginan dalam dirinya dan tindakantindakan yang dilakukan oleh kepala

\section{Daftar Pustaka}

[1] Anggriani, R. (2001). Analisis Pelaksanaan Perundang-undangan Rekam Medis Dalam Pengisian Rekam medis Instalasi Rawat Inap di RSUP Persahabatan Sebagai Alat Bukti dalam Tuntutan Hukum. Depok. Universitas Indonesia

[2] Arbain, Intan Indah. (2011). Gambaran pengetahuan Ibu Nifas tentang Kontrasepsi Metode Amenorea Laktasi (MAL) di Wilayah Kerja Puskesmas Pemaron Kec. Brebes Kab. Brebes rekam medis untuk memotivasi petugas dalam bekerja

3. Gambaran karakteristik organisasi pada rekam medis yaitu rekam medis merupakan sub bagian yang memiliki peran untuk mewujudkan visi dan misi Rumah Sakit. Memiliki struktur organisasi yang penanggung jawab keputusan adalah pimpinan, dan penganggung jawab teringgi adalah pimpinan yang tertinggi, dan seterusnya. Hubungan komunikasi antara kepala rekam medis dengan petugas rekam medis yang berjalan cukup baik sehingga dapat terpantau kinerja petugas. Dan untuk mengapresiasi kinerja pegawai, pegawai mendapatkan gaji dan jasa pelayanan serta apresiasi (reward) berupa ucapan terima kasih dan kegiatan yang dapat meningkatkan rasa kekeluargaan sehinga petugas dapat merasa nyaman dan bersemangat dalam bekerja.

4. Gambaran karakteristik pekerjaan pada rekam medis yaitu memiliki deskripsi pekerjaan dan jadwal pekerjaan yang jelas sehingga petugas memamahi tugas yang harus dilakukan sesuai dengan penempatan bagian dalam rekam medis.

Tahun 2011. Semarang: Universitas Muhammadiyah Semarang

[3] Arisandy, Moh. Rum. (2015). Pengaruh Keterampilan dan Pengalaman Kerja terhadap Pengembangan Karir Pegawai pada Dinas Pendidikan Kabupaten Donggala. e-Jurnal Katalogis. Volume 3 Nomor 8, 150

[4] Dindatia, Novi, dkk. (2017). Gambaran Kinerja Petugas Rekam Medis di Rumah Sakit Umum Daerah Kota 
Kediri Tahun 2017. Jurnal Ilmiah Kesehatan Masyarakat. Volume 2 Nomor 6

[5] Fahmi, Irham. (2012). Manajeman Kepemimpinan. Bandung: CV Alfabeta

[6] Kurniawati, Fitri, dkk. (2015). Gambaran Kinerja Petugas Rekam Medis Rumah Sakit PKU Muhammadiyah di Yogyakarta. Yogyakarta: Universitas Muhammadiyah Yogyakarta http://thesis.umy.ac.id.pdf (diakses pada 30 Juli 2018)

[7] Mulyono, Danan Dwi. (2012). Faktorfaktor yang Mempengaruhi Kinerja Pegawai Kantor Pelayanan Perbendaharaan Negara Surakarta. Palembang: Universitas Sriwijaya ejurnal.unisri.ac.idindex.phpMAParticl edownload812675.pdf (diakses pada 17 Mei 2018)

[8] Mustikawati, Farida, Indra Kurniawan. (2014). Pengaruh Job Description Terhadap Kinerja Karyawan Departemen Security Di PT Wilmar Nabati Indonesia-Gresik. Jurnal Fakultas Ekonomi. Volume 03 Nomor 02

[9] Profile Rumah Sakit Umum Daerah Cibinong Tahun 2016

[10] Rego, Apolinario Marcal Maia do. (2014). Pengaruh Imbalan, Motivasi dan Kepuasan Kerja terhadap Kinerja Pegawai Kejaksaan Agung dan
Kejaksaan Distrik Dili. Jurnal Ekonomi dan Bisnis. Volume 3 Nomor 10, 160

[11] Robbin, Stepen P. (2006). Perilaku Organisasi. Jakarta: PT. Indeks Kelompok Gramedia

[12] Sitorus, Andika Debora M. (2012) Gambaran Faktor-faktor yang Berhubungan dengan Kinerja Pegawai Instalasi Laboratorium Klinik RSUP Fatmawati Tahun 2012. Depok: Universitas Indonesia

[13] Sumampouw, TimotiusJ. (). Analisis Pelaksanaan Standar Minimal Pelayanan di Bagian Rekam Medis RSUD DR. Sam Ratulangi Tondano. Manado: Pascasarjana Universitas Sam Ratulangi

[14] Tsauri, Safira Hilwa. (2015). FaktorFaktor yang Mempengaruhi dengan Kinerja Pegawai Non PNS Unit Perbendaharaan di RSUD Pasar Rebo Wilayah Jakarta Timur Tahun 2015. Jakarta: Universitas Islam Negeri Syarif Hidayatullah

http://repository.uinjkt.ac.iddspacebi tstream123456789375551SAFIRA\% 20HILWA\%20TSAURI-FKIK.pdf (diakses pada 29 September 2018)

[15] Yulius, Saka. (2014). Pengaruh Kemampuan dan Motivasi terhadap kinerja pegawai bagian sekretariat di Dinas Perkerjaan Umum Provinsi Bengkulu. Bengkulu: Universitas Bengkulu. 